\author{
Bogdan Włodarczyk \\ Uniwersytet Łódzki \\ Instytut Geografii Miast i Turyzmu \\ Zakład Geografii Turyzmu \\ bogdan.wlodarczyk@geo.uni.lodz.pl
}

\title{
ŁÓDŹ JAKO ARENA WIELKICH WYDARZEŃ SPORTOWYCH - WYBRANE PRZYKŁADY
}

\begin{abstract}
Abstrakt: Opracowanie jest próbą przedstawienia Łodzi jako miejsca organizacji znaczących wydarzeń sportowych. Miasto dysponuje kilkoma obiektami sportowymi, które umożliwiają realizację różnego rodzaju spotkań, nawet o charakterze międzynarodowym. W ostatnich latach w oparciu o posiadaną infrastrukturę organizowane były przedsięwzięcia o randze mistrzostw Europy czy mistrzostw świata. Łódź postrzegana jest jako jeden z wiodących ośrodków jeśli chodzi o organizację zawodów związanych z piłką siatkową (mecze ligowe, Liga Mistrzów, Mistrzostwa Polski, Liga Światowa, Mistrzostwa Europy, Mistrzostwa Świata).
\end{abstract}

Słowa kluczowe: Łódź, sport, turystyka, infrastruktura sportowa, wydarzenia sportowe, turystyka sportowa, ruch turystyczny.

\section{WSTĘP}

Turystyka to nie tylko wypoczynek i zwiedzanie miejsc atrakcyjnych architektonicznie czy historycznie. To także podróże związane $\mathrm{z}$ uczestnictwem $\mathrm{w}$ wydarzeniach, $w$ tym $w$ wydarzeniach sportowych. $W$ literaturze naukowej i branżowej przewijają się $\mathrm{w}$ ostatnim czasie często określenia "turystyka sportowa" i "turystyka eventowa” czy "produkt turystyczny-wydarzenie". Jednak żadne $\mathrm{z}$ nich odpowiednio i w pełni nie określa rozwijającego się w szybkim tempie zjawiska, jakim jest tzw. fanoturystyka. Łódź z uwagi na doskonałe położenie komunikacyjne, dość dobrą bazę noclegową oraz stale rozwijające się zaplecze sportowe coraz częściej staje się areną wydarzeń sportowych o charakterze mistrzostw rangi krajowej, europejskiej, a nawet światowej.

Celem autora artykułu jest zaprezentowanie Łodzi jako ważnego w skali kraju ośrodka, w którym rozwija się turystyka sportowa. Badania ruchu turystycznego prowadzone w mieście w latach 2010-2012 wskazuja, że wydarzenia sportowe są głównym celem przyjazdu od 2 do $10 \%$ turystów, jako jeden z celów wymienia je od 5 do $12 \%$ respondentów. Wydarzenia sportowe organizowane $\mathrm{w}$ Łodzi dobrze $\mathrm{i}$ bardzo dobrze oceniane są przez $25-37 \%$ turystów (przy $60 \%$ odpowiedzi „nie mam zdania"). Jako jedną z głównych atrakcji miasta imprezy sportowe uznaje około $7-10 \%$ przyjezdnych (LISZEWSKI, red. 2010, WŁODARCZYK, red. 2011, 2012). Przedstawione wartości upoważniają do podjęcia szczegółowych studiów dotyczących Łodzi jako miasta, w którym ważną rolę odgrywają wydarzenia i turystyka sportowa.

Oprócz zagadnień teoretyczno-terminologicznych opracowanie prezentuje potencjał infrastrukturalny miasta związany z zagospodarowaniem sportowym oraz najważniejsze wydarzenia sportowe, które były w nim organizowane w ciągu ostatnich 10 lat. Szczególną uwage poświęcono Mistrzostwom Świata w Piłce Siatkowej Mężczyzn (2014), które przedstawiono jako studium przypadku. Wyniki badań pochodzą w części z opracowania K. SOBIERAJSKIEJ (2015), a także z materiałów będących podsumowaniem działalności i wysiłku organizacyjnego władz samorządowych.

\section{CHARAKTERYSTYKA TURYSTYKI SPORTOWEJ}

Turystyka sportowa jest przedmiotem zainteresowań naukowców zarówno w kontekście określenia jej istoty poprzez próbę jej zdefiniowania (m.in. GIBSON 1998, 
WEED, BULL 2005, KUREK 2007, KOZAK 2010, HINCH, HiGHAM 2011, KAZIMIERCZAK, MALCHROWICZ-MOŚKO 2013, STASIAK, WŁODARCZYK 2015), jak i lokalizacji w licznych podziałach turystyki jako zjawiska (m.in. HINCH, HIGHAM 2011, BOŃCZAK 2013a, 2013b, MOKRAS-GRABOWSKA 2015, STASIAK, WŁODARCZYK 2015). $W$ analizach turystyki sportowej, jako oryginalnej aktywności o charakterze turystycznym, wyraźnie zarysowuje się także nurt poświęcony wydarzeniom sportowym jako istotnym czynniku stymulującym podejmowanie takiej aktywności (m.in. OTTEVANGER 2007, ROSE, SPIEGEL 2011, BUDNER 2014, HADZIK, TOMIK, RYŚNIK 2015, KOZAK 2015, PIECHOTA 2015). Turystyka sportowa jest też przedmiotem licznych badań empirycznych, które w większości koncentrują się na wpływie wielkich wydarzeń sportowych na różne aspekty funkcjonowania miejsc, w których są organizowane (m.in. TUREK 2007, KOZAK 2010, ŚNIADEK 2013, BOSIACKI 2015, SZNAJDER 2015).

Turystyka sportowa określana jest jako odbywanie krótkich podróży poza środowisko zamieszkania, nastawione na udział w sporcie, przy czym sport charakteryzują określone reguły, najczęściej to, że współzawodnictwo związane jest z podnoszeniem sprawności fizycznej i zabawą (HINCH, HIGHAM 2011). Nieco szerzej pojęcie turystyki sportowej definiuje M. KOZAK, (2010) uznając, że jest to zespół zachowań turystów stanowiących ich autentyczne zainteresowanie sportem (obiektami, miejscami ważnych wydarzeń itp.), ale również ich uczestnictwo w szeroko rozumianym współczesnym życiu sportowym. Inne ujęcie, związane bardziej $\mathrm{z}$ aspektami kulturowymi zjawiska, przedstawiają autorzy podręcznika Turystyka uznając, że turystyka sportowa polega na uczestniczeniu jako widz lub kibic w wydarzeniach sportowych, wobec czego zalicza się do form turystyki poznawczej, która dotyczy rozwoju wewnętrznego, a więc kulturowego człowieka (KUREK, red. 2007). Tym samym jest częścią turystyki kulturowej, czyli odbywaniem podróży w celu m.in. wzięcia udziału w wydarzeniach kulturalnych (w tym sportowych).

W literaturze pojęcie „turystyka sportowa” zostało wprowadzone stosunkowo niedawno i być może stąd biorą się nieścisłości w jego definiowaniu. Większość badaczy do turystyki sportowej zalicza wszelkie formy aktywności turystycznej związane ze sportem, co stanowi ogromne uogólnienie i opisuje co najmniej kilka różnych zjawisk. Jak wynika z rozważań przedstawionych wcześniej definicje zazwyczaj dookreślają turystykę sportową jako podróżowanie w celu obejrzenia wydarzenia sportowego, osobistego brania w nim udziału lub też jako podróżowanie związane z poznawaniem miejsc i obiektów sportowych, nawet gdy nie odbywają się w tym czasie żadne wydarzenia (np. WEED, BULL 2005). Tak różnorodnie definiowaną turystykę sportową można podzielić na kilka kategorii, do których należą:

- turystyka sportowa czynna - wyjazdy związane z osobistym udziałem w imprezach sportowych w charakterze zawodnika;

- turystyka sportowa poznawcza - zwiedzanie obiektów sportowych, często historycznych - np. stadiony olimpijskie, wielkie obiekty piłkarskie, tory wyścigowe, korty Wimbledonu itd.;

- turystyka wydarzeń sportowych (fanoturystyka) - udział w imprezach sportowych w charakterze widza (kibica).

Obok turystyki sportowej używane jest również pojęcie „fanoturystyka”. Termin ten powstał z połączenia słów: "fan"(z ang. kibic) oraz "turystyka". Jest to określenie definiujące wyjazdy turystyczne w celu oglądania wydarzeń sportowych. Głównym motywem jej uprawiania jest chęć wspierania ulubionej drużyny w drodze do zwycięstwa podczas rozgrywanych zawodów. Fanoturystyka związana jest z imprezami o charakterze międzynarodowym - igrzyskami czy mistrzostwami świata, ale obejmuje także wydarzenia o niższej randze, organizowane lokalnie czy regionalnie (BRUMM 2012).

Wewnętrznie fanoturystkę można podzielić jeszcze na groundhopping (tj. kibicowanie, czyli aktywny udział $\mathrm{w}$ imprezach sportowych) oraz groundspotting (zwiedzanie, oglądanie obiektów związanych z organizacją wydarzeń sportowych). Oba pojęcia powstały na początku lat 90. XX w. i trwale zagościły w terminologii branżowej (STASIAK, WŁODARCZYK 2015).

W Polsce określenie „fanoturystyka” pojawia się sporadycznie i stosowane jest w przypadku podróży, których celem jest kibicowanie drużynie narodowej, klubom sportowym lub poszczególnym sportowcom, jednak w literaturze naukowej nie zostało ono jeszcze dokładnie zdefiniowane. Zasadnicza różnica pomiędzy turystyką sportową a fanoturystyką polega więc na tym, że w pierwszym przypadku mamy do czynienia $z$ chęcią uprawiania sportu i aktywnej rekreacji, zaś w drugim chodzi o oglądanie zawodów sportowych (KUREK, red. 2007).

Turystykę sportową związaną wydarzeniami sportowymi (sport event tourism) z pewnością traktować można jako punkt wyjścia do organizacji produktu turystycznego typu wydarzenie. Jest to produkt, który stanowi zaplanowane i zorganizowane zdarzenie integrujące w sobie poszczególne usługi, walory turystyczne, a najważniejszym elementem tej integracji jest organizacja, zarządzanie i konkretna lokalizacja. Specyficznymi cechami produktu turystycznego-wydarzenie są: duża spójność tematyczna i organizacyjna, konkretna lokalizacja i termin, wyjątkowość oraz często cykliczność (KACZMAREK, STASIAK, WŁODARCZYK 2010). 
Istnieje coraz więcej pakietów turystycznych, które są dopasowywane do potencjalnych potrzeb odbiorców tego rodzaju imprez. Największą popularnością cieszą się megawydarzenia, do których zaliczyć można igrzyska olimpijskie, mistrzostwa świata w piłce nożnej, lekkoatletyce czy też wyścigi Formuły 1. Mniejsze wydarzenia wybierane są zazwyczaj przez kibiców drużyn i sportowców biorących w nich udział lub też przez osoby związane z konkretną dyscypliną sportu. W ramach większości pakietów oferowane są m.in.: bilety wstępu na imprezę sportową, transport, zakwaterowanie, wyżywienie, zwiedzanie miasta lub innych punktów na trasie, a czasem także spotkania $\mathrm{z}$ zawodnikami, zwiedzanie obiektów sportowych oraz inne atrakcje dedykowane temu specyficznemu segmentowi rynkowemu.

Turystykę sportowo-eventową można podzielić jeszcze na twardą (hard sport event tourism) i miękka (soft sport event tourism) (RITCHE, ADAIR 2004). Do pierwszej zalicza się klientów podejmujących podróż przede wszystkim ze względu na chęć uczestnictwa w wydarzeniu sportowym, a wszelkie inne punkty wyjazdu (np. zwiedzanie) są jedynie dodatkami. Miękka turystyka sportowo-eventowa obejmuje takie wyjazdy, w których podstawową funkcją jest wypoczynek, poznanie itd., a niejako przy okazji turysta decyduje się na wzięcie udziału w wydarzeniu sportowym. Zazwyczaj im wyższa jest ranga imprezy i popularność dyscypliny, tym większy jest udział turystyki twardej, zaś w wydarzeniach o niższej randze uczestnictwo jest częściej przypadkowe.

Przy tworzeniu produktu turystycznego z wydarzenia sportowego bardzo istotna jest ranga danej imprezy, która pozwala oszacować skalę wydarzenia, a więc i liczbę potencjalnych turystów (kibiców) zainteresowanych przyjazdem do danego miasta. J. KACZMAREK, A. STASIAK i B. WŁODARCZYK (2010) dzielą za G. Bowdin i in. (2003) wydarzenia na cztery kategorie ze względu na ich zasięg i rangę:

1) megawydarzenia - wydarzenia mające wpływ na ekonomię znacznego obszaru, szeroko relacjonowane w mediach krajowych i międzynarodowych (np. igrzyska olimpijskie, mistrzostwa świata);

2) wydarzenia wyróżniające - imprezy rozpoznawalne i kojarzone $\mathrm{z}$ miastem lub krajem, stanowiące interesujący produkt turystyczny poprzez swoją unikatowość i rangę (m.in. wielkie maratony, mistrzostwa klubowe);

3) wydarzenia większe - wydarzenia o mniejszej randze, ale dobrze wypromowane, przez co skala imprezy i zainteresowania mediów przekłada się na dochody organizatora i miasta (np. mistrzostwa kraju, piłkarskie derby miast);

4) wydarzenia lokalne - niewielkie imprezy; niskie nakłady na organizację i promocję, skutkują małą rozpoznawalnością, zainteresowaniem mediów i frekwencją turystów (takie, jak rozgrywki klubów lokalnych).

Każda z wymienionych grup definiuje imprezy o innej randze i skali, a co za tym idzie grupę docelową będą stanowić inni odbiorcy. W przypadku np. igrzysk olimpijskich (megawydarzenie) odbiorcą będzie turysta masowy, nastawiony na atmosferę wielkiego sportowego święta, podczas gdy przy wydarzeniach lokalnych, największy nacisk trzeba położyć na promocję w miejscu rozgrywania imprezy, skupiając się głównie na lokalnych kibicach danej drużyny lub zawodnika.

W. ALEJZIAK (2008) uważa, że wydarzenia sportowe zajmują szczególną pozycję wśród czynników, które przyciągają turystów do danej destynacji. Wiąże się to m.in. z niepowtarzalnością każdego wydarzenia, emocjami, jakie niesie sport, stale zmieniającą się lokalizacją wydarzeń, a co za tym idzie, odmiennością kulturową. Widowiskowość i nieprzewidywalność sportu doskonale wpisują się w oczekiwania współczesnego turysty. Dodatkową atrakcją dla uczestnika takiego wydarzenia jest jego medialność. Współczesny kibicturysta chce osobiście brać udział w imprezie, którą śledzą miliony widzów, a nie jedynie za pośrednictwem mediów. On czuje się wyróżniony, że ogląda dane wydarzenie $z$ trybun. Wszystkie te czynniki powodują, że turystyka sportowo-eventowa ma coraz większe znaczenie, a o organizację imprez najwyższej rangi trwa zazwyczaj „walka” pomiędzy państwami i miastami. Dzieje się tak dlatego, że wielkie imprezy sportowe mają tę zaletę, że są krótkimi wydarzeniami z długoterminowymi konsekwencjami. Przedstawione opinie podziela także A. HADZIK (2014), który odnosi te zagadnienia do wielkich międzynarodowych wydarzeń sportowych.

B. FAULKNER (1993) wymienia sfery, na które oddziałuje organizacja wydarzeń sportowych. Zdaniem tego autora, imprezy sportowe wpływają na ekonomię, turystykę oraz środowisko obszaru, na którym są organizowane. Skutki wydarzeń sportowych B. FAULKNER (1993) klasyfikuje następująco:

1) ekonomiczne, w tym:

- wydatki przyjezdnych,

- wydatki władz na infrastrukturę,

- wydatki organizatorów wydarzenia;

2) turystyczne, w tym:

- zmiany w motywacjach turystycznych,

- znaczenie mediów w promocji wydarzenia;

3) środowiskowo-społeczne, w tym:

- wpływ na środowisko przyrodnicze,

- udogodnienia i dostęp do usług, dóbr itp.,

- wpływ społeczno-kulturowy i psychologiczny.

M. KOZAK (2010) wymienia także cztery aspekty turystyki sportowej, które są bezpośrednio związane $z$ organizacją wydarzeń sportowych: 
1) ekonomiczny - dotyczący nakładów pieniężnych związanych $\mathrm{z}$ organizacją międzynarodowych wydarzeń sportowych;

2) społeczny - gdzie wydarzenia sportowe wpływają motywująco na umacnianie dumy narodowej;

3) promocyjny - polegający na promowaniu miejsca, w którym odbywa się wydarzenie;

4) planistyczny - określający wpływ organizacji imprez na rozwój obszaru recepcyjnego.

Zyski osiągane poprzez organizację wydarzeń sportowych to przede wszystkim wpływy pochodzące od uczestników wydarzenia.

Według. J. BORZYSZKOWSKIEGO (2011) istnieją również inne personalne źródła wpływów finansowych z wydarzenia sportowego, wśród których można wymienić:

1) widzów - opłaty za wstęp i inne wydatki;
2) graczy - wpisowe, wydatki związane z udziałem w imprezie (np. sprzęt), inne wydatki (np. noclegi, wyżywienie);

3) wolontariuszy i współpracowników - wartość pracy wolontariuszy, inne;

4) media, sędziów i innych uczestników, gospodarzy i sponsorów;

5) wystawców oraz dostawców usług i dóbr.

Dotychczasowe rozważania pokazują, jak ważnym i wieloaspektowym działaniem jest organizacja dużych wydarzeń o charakterze sportowym.

\section{INFRASTRUKTURA SPORTOWA MIASTA}

Powstanie pierwszych obiektów sportowych w Łodzi miało miejsce $\mathrm{w}$ początkach $\mathrm{XX} \mathrm{w}$. i związane było z klubami/towarzystwami piłkarskimi, często wspieranymi przez miasto poprzez przeznaczanie terenów

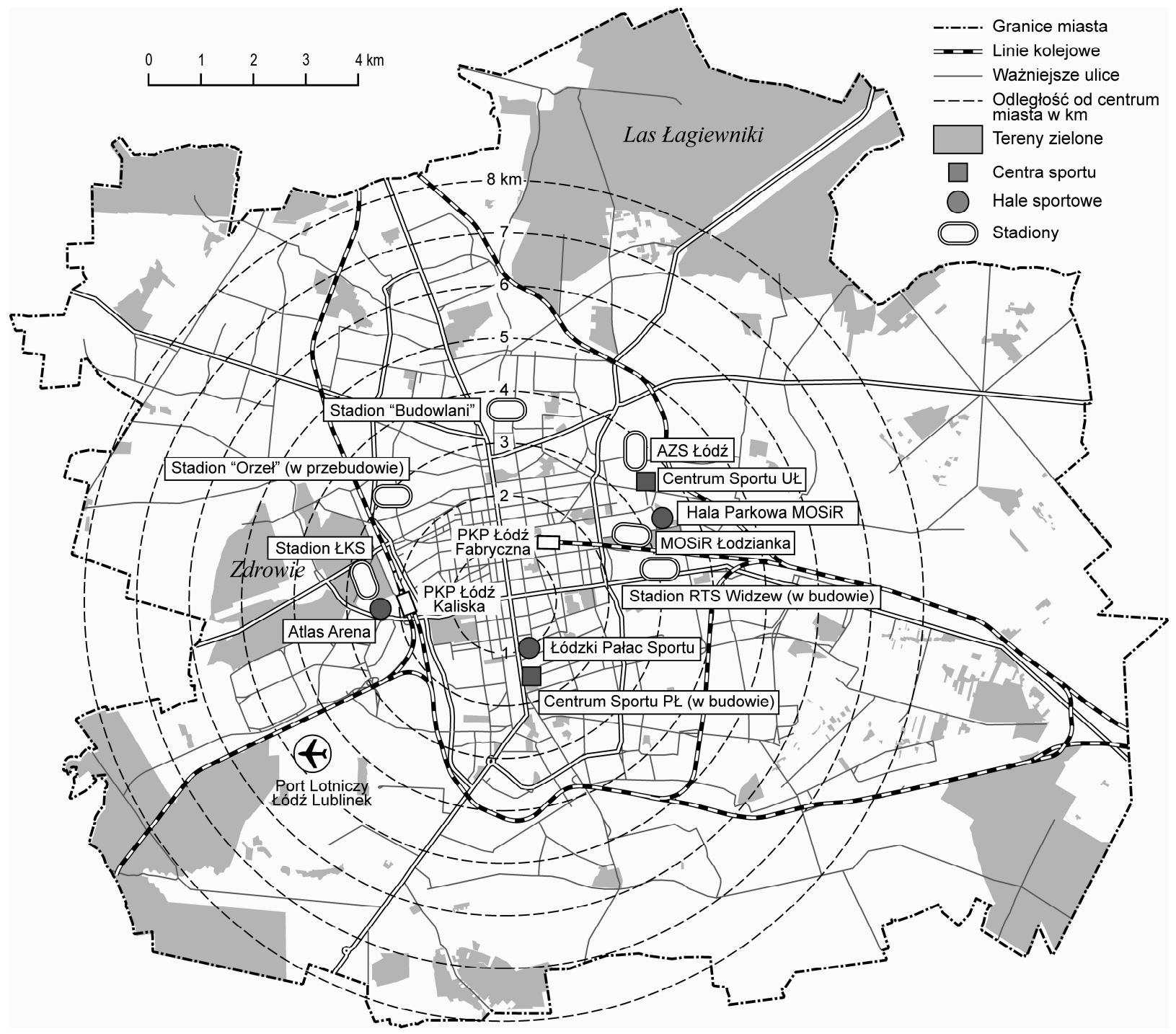

Rys. 1. Rozmieszczenie ważniejszych obiektów sportowych w przestrzeni miejskiej Łodzi Źródło: opracowanie autora 
miejskich na pierwsze inwestycje. Obecnie Łódź, jako trzecia pod względem liczby ludności metropolia w Polsce, charakteryzuje się dość dobrze rozwiniętą bazą sportową, w oparciu o którą można organizować imprezy rangi krajowej czy międzynarodowej. Oczywiście nie jest to poziom, który można byłoby uznać za całkowicie zadowalający. Jednak podejmowane w mieście nowe inwestycje oraz inicjatywy nastrajają optymistycznie.

Cechą charakterystyczną rozmieszczenia ważniejszych obiektów, w których organizowane imprezy sportowe, jest ich lokalizacja tuż na zapleczu atrakcyjnego turystycznie ścisłego centrum miasta (rys. 1). $Z$ jednej strony sprzyja to zwiedzaniu Łodzi niejako "przy okazji”, ale jednocześnie powoduje brak zapewnienia wystarczającej liczby miejsc parkingowych niezbędnych podczas organizacji wielkich imprez o charakterze międzynarodowym.

Do najbardziej znanych obiektów, które w przeszłości i obecnie kojarzone są z ważnymi wydarzeniami sportowymi, należą: Łódzki Pałac Sportu, Atlas Arena, łódzkie stadiony miejskie związane $\mathrm{z}$ klubami piłkarskimi Widzew i ŁKS (fot. 1-4.). Szerzej zostaną one opisane w dalszej części artykułu.

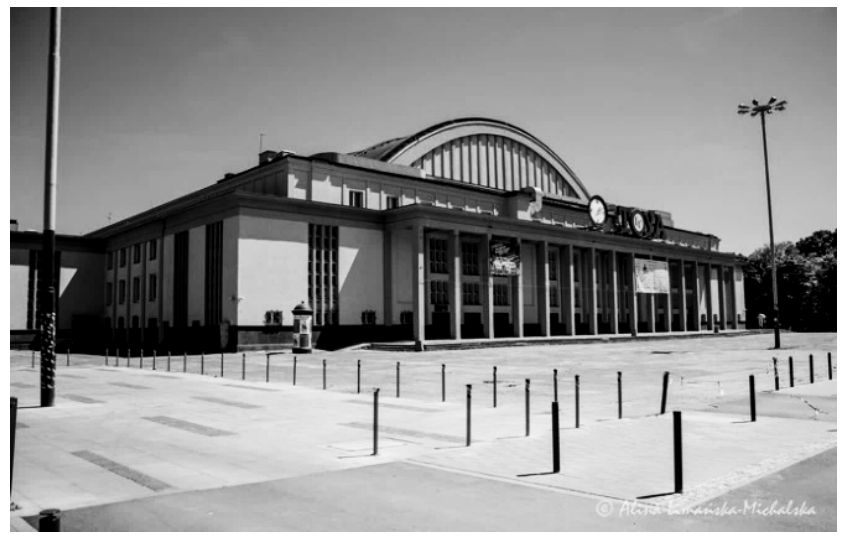

Fot. 1. Pałac Sportu w Łodzi Źródło: http:/ / myself.rogatek.pl

Ważne miejsce w historii rozwoju łódzkiego sportu oraz wydarzeń kulturalnych do niedawna odgrywała otwarta w 1957 r. hala sportowa nazywana później Palacem Sportu (fot. 1). W początkowym okresie funkcjonowania uchodziła za najnowocześniejszy tego typu obiekt w Polsce. Na trybunach mogło pomieścić się wówczas około 9 tys. osób. Odbywały się w niej nie tylko wydarzenia sportowe (mecze bokserskie, mecze siatkówki, pokazy łyżwiarskie i mecze hokeja), ale także duże imprezy kulturalne, takie jak koncerty zespołów muzycznych, pokazy filmowe, spotkania ze znanymi ludźmi oraz świąteczne targi, czyli słynna „Łódzka Gwiazdka”. W ostatnich latach (1998-2008) organizowano w niej mecze siatkówki w ramach Ligi
Światowej, w których uczestniczył najbardziej znany klub siatkarski województwa łódzkiego "Skra" Bełchatów. Po oddaniu do użytku obiektu Atlas Arena Pałac Sportu stracił na znaczeniu, odbywały się w nim najczęściej różne imprezy targowe (np. Interstone). Obecnie hala wymaga generalnego remontu płyty głównej i widowni. W zespole pomieszczeń funkcjonuje tu Oddział Sportu i Turystyki Muzeum Miasta Łodzi, w którym można oglądać m.in. takie stałe ekspozycje, jak: Z dziejów łódzkiego sportu, Największe osiagnięcia łódzkich sportowców, Łodzianie w igrzyskach olimpijskich.

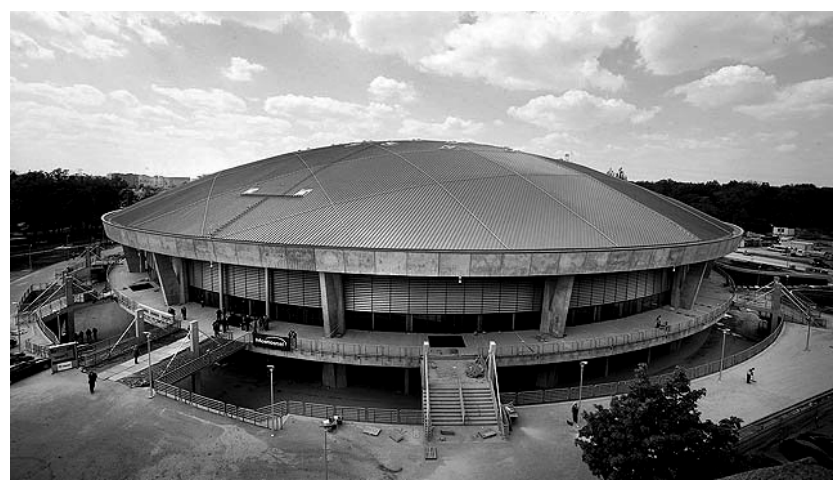

Fot. 2. Atlas Arena w Łodzi

Źródło: http://www.eventim.pl

Hala widowiskowo-sportowa Atlas Arena (fot. 2) jest jednym $\mathrm{z}$ największych tego typu obiektów w Polsce, oddanym do użytku w czerwcu 2009 r. Oferuje kompleksową obsługę zarówno dla organizatorów imprez sportowych, jak i estradowych. Jest przystosowana do organizacji różnego rodzaju imprez sportowych z takich dyscyplin, jak m.in.: koszykówka, siatkówka, piłki ręczna, halowa piłka nożna, sporty walki, enduro i wiele innych (tab. 1).

Obiekt jest wyposażony w nowoczesną infrastrukturę spełniającą wymogi międzynarodowych federacji i organizacji sportowych. Ukształtowanie i sposób konstrukcji płyty głównej umożliwia także ulokowanie na niej lodowiska, a nawet basenu z wodą. Funkcjonalność obiektu pozwala na rozdzielenie od siebie stref komunikacyjnych, przeznaczonych dla artystów, sportowców, obsługi, gości VIP oraz widzów. Arena dysponuje salą treningową, własną sceną modułową oraz pomieszczeniami konferencyjnymi. Oprócz imprez sportowych organizowane są w niej koncerty, imprezy targowe oraz spotkania wymagające dużej liczby miejsc siedzących. Obiekt udostępniony jest dla 13806 widzów (trybuna stała na 10049 miejsc, trybuna teleskopowa - 2060 miejsc, 1697 - miejsc dostawnych). Do czasu oddania do użytku Ergo Areny w Sopocie (2010) oraz Tauron Areny w Krakowie (2014) Atlas Arena była największym i najnowocześniejszym obiektem tego typu w Polsce. 
Tab. 1. Wybrane wydarzenia sportowe organizowane w hali widowiskowo-sportowej Atlas Arena w latach 2009-2016

\begin{tabular}{|c|c|c|}
\hline Rok & Wydarzenie sportowe & $\begin{array}{l}\text { Dyscyplina } \\
\text { sportu }\end{array}$ \\
\hline \multirow{7}{*}{2009} & Liga Światowa & siatkówka \\
\hline & Marcin GortatCamp & koszykówka \\
\hline & Memoriał Huberta Jerzego Wagnera & siatkówka \\
\hline & $\begin{array}{l}\text { Mistrzostwa Europy w Koszykówce } \\
\text { Mężczyzn }\end{array}$ & koszykówka \\
\hline & $\begin{array}{l}\text { Mistrzostwa Europy w Siatkówce } \\
\text { Kobiet }\end{array}$ & siatkówka \\
\hline & Gala Boksu Zawodowego & boks \\
\hline & Polsat Boxing Night & boks \\
\hline \multirow{4}{*}{2010} & Gala Boksu Zawodowego & boks \\
\hline & Wojak Boxing Night & sztuki walki \\
\hline & $\begin{array}{l}\text { Gala MMA (Mixed Martial Arts) } \\
\text { Fighters }\end{array}$ & sztuki walki \\
\hline & XVI Konfrontacja Sztuk Walki & sztuki walki \\
\hline \multirow{4}{*}{2011} & Liga Światowa & siatkówka \\
\hline & \begin{tabular}{|l|} 
Zawodowa Gala MMA: Fighters \\
Arena Łódź 2 \\
\end{tabular} & sztuki walki \\
\hline & $\begin{array}{l}\text { Mistrzostwa Europy w Koszykówce } \\
\text { Kobiet }\end{array}$ & koszykówka \\
\hline & XVII Konfrontacja Sztuk Walki & sztuki walki \\
\hline \multirow{6}{*}{2012} & XIX Konfrontacja Sztuk Walki & sztuki walki \\
\hline & Wielka Gala Boksu Zawodowego & boks \\
\hline & \begin{tabular}{|l|} 
Mistrzostwa Świata w Karate Trady- \\
cyjnym
\end{tabular} & karate \\
\hline & Monster X Truck & sporty motorowe \\
\hline & Mistrzostwa Świata Super Enduro & sporty motorowe \\
\hline & Eliminacje do Pucharu Davisa & tenis \\
\hline \multirow{3}{*}{2013} & $\begin{array}{l}\text { WWE Raw Wrestlemania Revenge } \\
\text { Tour }\end{array}$ & sztuki walki \\
\hline & $\begin{array}{l}\text { Mistrzostwa Świata FIM Super } \\
\text { Enduro } \\
\end{array}$ & sporty motorowe \\
\hline & XXIV Konfrontacja Sztuk Walki & sztuki walki \\
\hline \multirow{4}{*}{2014} & $\begin{array}{l}\text { Mistrzostwa Świata w Piłce Siatkowej } \\
\text { Mężczyzn }\end{array}$ & siatkówka \\
\hline & Łódź Maraton Dbam o Zdrowie & $\begin{array}{l}\text { biegi długo- } \\
\text { dystansowe }\end{array}$ \\
\hline & Puchar Polski w Siatkówce Kobiet & siatkówka \\
\hline & $\begin{array}{l}\text { Kwalifikacje do Mistrzostw Świata } \\
\text { w Siatkówce Kobiet }\end{array}$ & siatkówka \\
\hline \multirow{5}{*}{2015} & Pedro's Cup & lekkoatletyka \\
\hline & Polsat Boxing Night & boks \\
\hline & Mistrzostwa Świata Super Enduro & sporty motorowe \\
\hline & Liga Mistrzów & siatkówka \\
\hline & Łódź Maraton DoZ & $\begin{array}{l}\text { biegi długo- } \\
\text { dystansowe }\end{array}$ \\
\hline \multirow{3}{*}{2016} & Liga Światowa & siatkówka \\
\hline & Łódź Maraton DoZ & $\begin{array}{l}\text { biegi długo- } \\
\text { dystansowe }\end{array}$ \\
\hline & Liga Mistrzów & siatkówka \\
\hline
\end{tabular}

Źródło: opracowanie autora na podstawie danych MOSiR Łódź

Stadion miejski (MOSiR) w Łodzi (fot. 3), kojarzony od zawsze z Łódzkim Klubem Sportowym, przechodził różne koleje losu. Po odzyskaniu w 1918 r. niepodległości pierwszy prezydent Łodzi Aleksy Rżew- ski zainicjował w 1922 r. powstanie Parku Sportowego, z którego miał korzystać istniejaccy od ponad dekady ŁKS. Władze miasta przekazały klubowi dziesięciomorgowy teren na Polesiu Konstantynowskim. Częścią kompleksu był stadion piłkarski zbudowany w latach 1924-1925.

Najważniejszą modernizację podupadłego obiektu wykonano w latach 1969-1970. Najpierw otwarto nową trybunę główną, na zapleczu której poza standardowymi pomieszczeniami administracyjnymi znalazła się hala widowiskowa, służąca później, przez ponad 40 lat, sekcjom koszykarskim i siatkarskim. Rok później uruchomiono oświetlenie na czterech wysokich masztach. Z kolei w 1971 r., już na odnowionym obiekcie, oglądało mecz ŁKS z Polonią Bytom aż 45 tys. widzów.

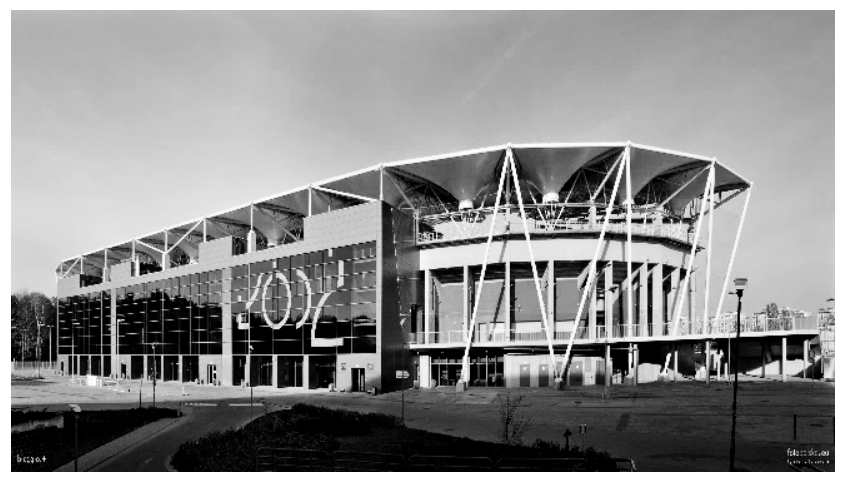

Fot. 3. Stadion miejski (ŁKS - w budowie) Źródło: http:/ / fotopolska.eu/stadiony

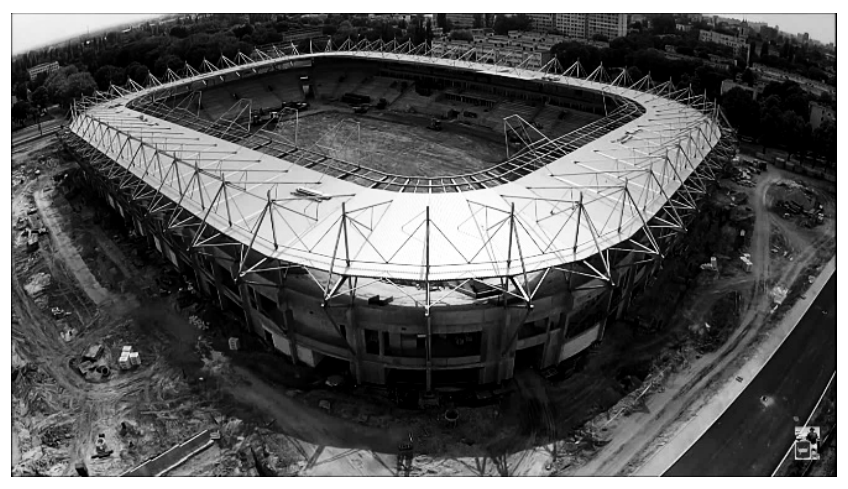

Fot. 4. Stadion miejski (RTS Widzew - w budowie) Źródło: https://www.youtube.com

W latach 90. minionego stulecia obiekt niszczał. W 2007 r. ŁKS przekazał stadion samorządowi miejskiemu, by ten sfinansował i przeprowadził kompleksową modernizację. W roku 2009 miasto przeprowadziło konkurs architektoniczny, ale pomysł stadionu na około 30 tys. widzów nie doczekał się realizacji. W 2011 r. powstała koncepcja wzniesienia nowego stadionu częściowo $\mathrm{w}$ miejscu obecnego, tym razem dla 16,5 tys. widzów, za to $\mathrm{z}$ możliwością rozbudowy 
(http:/ / stadiony.net/stadiony/pol/stadion_lks_lodz. Obecnie składa się on $\mathrm{z}$ boiska i jednej trybuny. Ta ostatnia ma m.in. efektowną, częściowo szklaną elewację zewnętrzną z napisem "Łódź”, kilka poziomów wewnętrznych, na których znajdują się przestronne szatnie, sauny, gabinety odnowy biologicznej, sale konferencyjne itp. (http://www.fakt.pl/sport/pilkanozna).

Stadion miejski (RTS Widzew) (fot. 4) został wybudowany w latach 30 . XX w. i był kilkakrotnie modernizowany. Od końca lat 50 . XX w. na terenie pomiędzy torami kolejowymi a ul. Armii Czerwonej (obecnie Piłsudskiego) prowadzone były prace przy rozbudowie stadionu piłkarskiego. Intensyfikacja działań nastąpiła w drugiej połowie lat 70., po awansie piłkarzy do ekstraklasy. Wyburzono starą drewnianą trybunę od strony ulicy Tunelowej, zlikwidowano bieżnię i postawiono nowe trybuny, wybudowane na podstawie usypanych wałów ziemnych (na których później ukształtowano betonowe miejsca na ławki i koronę stadionu). Trybuny usytuowano dość blisko płyty boiska, tworząc obiekt typowo piłkarski. Na początku roku 2015 został rozebrany wraz z budynkiem klubowym i sala sportową. Obecnie trwa budowa nowego stadionu o pojemności 18018 miejsc siedzących. Obiekt powstaje $\mathrm{w}$ tym samym miejscu co poprzedni i zgodnie z przyjętym harmonogramem ma zostać oddany do użytku do końca listopada 2016 r. (https:/ / pl.wikipedia.org/wiki/Stadion_Widzewa).

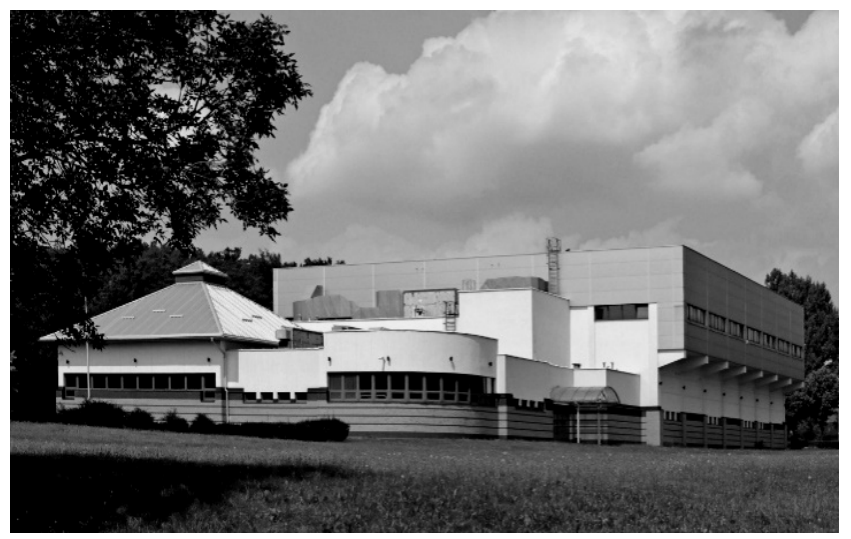

Fot. 5. Hala Parkowa w Łodzi Źródło: http:/ / lodz.fotopolska.eu

Opisane cztery sztandarowe obiekty sportowe miasta uzupełnia jeszcze hala Parkowa (MOSiR) (fot. 5) zlokalizowana obok kompleksu boisk Łodzianka (m.in. stadion $\mathrm{z}$ pełnowymiarowym boiskiem piłkarskim z nawierzchnią trawiastą, z trybunami, okolony ośmiotorową bieżnią, kompleksem boisk typu „orlik", dwoma boiskami do siatkówki plażowej, boiskiem do piłki nożnej plażowej oraz pięcioma kortami tenisowymi, wielofunkcyjna hala sportowa - sala główna o wymiarach $23 \times 43 \mathrm{~m}$, sala lustrzana o wymiarach
$14 \times 14 \mathrm{~m}$, sauna sucha i sześć szatni sportowych) oraz miasteczko ruchu drogowego.

Niebagatelną rolę w przestrzeni sportowej miasta odgrywają obiekty związane z uczelniami akademickimi. Jednym z nich jest Centrum Sportu Uniwersytetu Łódzkiego (m.in. hala sportowa, basen) wraz z obiektami Akademickiego Zespołu Sportowego (AZS) (stadion lekkoatletyczny, boisko piłkarskie, hala tenisowa). W najbliższym czasie (maj 2017 r.) infrastruktura sportowa Łodzi zostanie powiększona o inwestycje Łódzkiego Akademickiego Centrum Sportowo-Dydaktycznego - „Zatoka Sportu” (Politechnika Łódzka). W skład "Zatoki Sportu" wchodzić będą m.in. 10-torowy basen olimpijski o długości $50 \mathrm{~m} \mathrm{z}$ trybunami dla 1200 widzów, 30-metrowy basen z trampolinami, podestami oraz wielopoziomową wieżą do skoków o wysokości $10 \mathrm{~m}$, ścianka wspinaczkowa wraz ze ścianką treningową (bulderową), wielofunkcyjna i pełnowymiarowa sala sportowa przeznaczona również do multimedialnych prezentacji kulturalnych, wraz z widownią i platformą TV. W obiekcie planowane jest rozgrywanie zawodów pływackich i wspinaczkowych rangi mistrzostw Europy.

Ważnymi obiektami związanymi z tradycyjnie uprawianymi w Łodzi dyscyplinami sportu w przyszłości powinny stać się modernizowany obecnie stadion żużlowy "Orzeł" (fot. 6), a także stadion rugby „Budowlanych" Łódź.

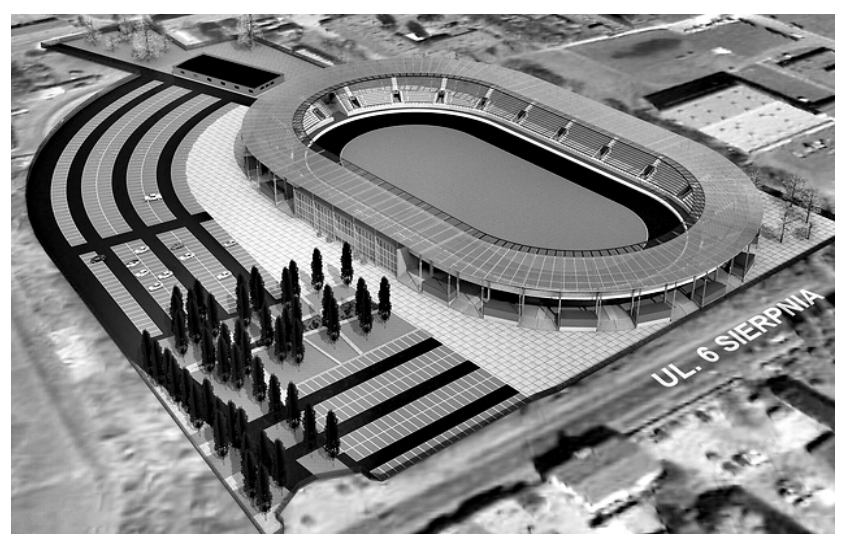

Fot. 6. Wizualizacja nowego stadionu „Orła” http:/ / sportowefakty.wp.pl/zuzel/416277/znamywizualizacje-stadionu-orla-lodz

\section{WIELKIE WYDARZENIA SPORTOWE W ŁODZI - WYBRANE PRZYKŁADY}

Decyzje dotyczące organizacji dużych wydarzeń sportowych podejmowane są zazwyczaj z nadzieją na osiągnięcie określonych wymiernych korzyści, do których należą:

- zwrot kosztów poniesionych na organizację wydarzenia; 
- osiągnięcie przewidywanego, zadowalającego zysku z organizowanego wydarzenia;

- korzyści finansowe dla hotelarzy, restauratorów oraz innych przedsiębiorców świadczących usługi dodatkowe;

- wzrost zainteresowania miejscem organizacji wydarzenia wśród kibiców biorących udział w wydarzeniu;

- umocnienie lub budowa pozytywnego wizerun$\mathrm{ku}$ gospodarza wydarzenia ( $\mathrm{w}$ tym tzw. ekwiwalent reklamowy).

Przed wybudowaniem Atlas Areny w 2009 r. w Łodzi odbywało się niewiele imprez sportowych. Rolę największego i najważniejszego obiektu sportowego w mieście odgrywała hala sportowa Miejskiego Ośrodka Sportu i Rekreacji. Od 1999 r. aż do wybudowania Atlas Areny rozgrywane w niej były mecze Ligi Światowej siatkarzy.

Od 2009 r., odkąd została wybudowana Atlas Arena, która stała się najważniejszym obiektem sportowo-widowiskowym w mieście, nastąpił wzrost liczby wydarzeń o charakterze sportowym. Imprezą otwarcia Atlas Areny był mecz w ramach Ligi Światowej pomiędzy Polską a Brazylią.

Od 2004 roku w Łodzi odbywa się uliczna impreza biegowa pod nazwą „Łódź Maraton Dbam o Zdrowie". Przez pierwsze sześć lat organizowania się biegu nosił on nazwę "mBank Łódź Maraton”. Niestety w 2010 r. bieg się nie odbył ze względu na wycofanie się sponsora tytularnego. W czerwcu 2011 r. impreza została reaktywowana pod nazwą „Łódź Maraton Dbam o Zdrowie", a jej biuro zostało umieszczone w Atlas Arenie. Bieg obejmuje kilka tras: główna trasa o długości ponad $42 \mathrm{~km}$ przebiega przez dwie dzielnice miasta: Śródmieście i Polesie. Co roku trasa ma nieco odmienny przebieg od poprzedniej edycji, ale start zawsze odbywa się w alei Unii Lubelskiej przy Aquaparku Fala, a meta znajduje się na terenie Atlas Areny. Ponadto $\mathrm{w}$ ramach imprezy przygotowywane są krótsze trasy: na $10 \mathrm{~km}$ oraz ścieżki biegowe dla najmłodszych. Bieg cieszy się rosnącą popularnością, z roku na rok uczestniczy w nim coraz więcej osób, nie tylko z Polski, ale i z całego świata. W 2011 r. wzięło w nim udział prawie 500 osób, w 2012 było to już 2200 uczestników z 21 krajów. Dwie kolejne edycje maratonu zgromadziły po około 4000 biegaczy, a sama impreza otrzymała prestiżowe wyróżnienie - certyfikat Międzynarodowej Federacji Lekkoatletycznej IAAF, brązowy w 2013 i srebrny w 2014 r. (www.lodz.sport. pl). Impreza co roku jest relacjonowana na żywo przez Telewizję Polską, a w wielu innych stacjach telewizyjnych pojawiają się reportaże dotyczące biegu. Poza promowaniem aktywności sportowej bieg ma również inny cel - zbiórkę pieniędzy na rzecz wybranej organizacji będącej partnerem wydarzenia. Maraton obec- nie na stałe wpisał się w harmonogram łódzkich imprez sportowych.

Ważniejszymi wydarzeniami sportowymi, które odbyły się w Łodzi w 2009 r. były Mistrzostwa Europy w Koszykówce Mężczyzn oraz w Piłce Siatkowej Kobiet. Mecze drugiej fazy grupowej Mistrzostw Europy w Koszykówce Mężczyzn rozgrywane były w Atlas Arenie w terminie od 12 do 16 września. W łódzkiej hali rozegranych zostało dziewięć meczów, podczas których można było zobaczyć reprezentacje Hiszpanii, Litwy, Polski, Serbii, Słowenii i Turcji. Reprezentacja Polski zajęła 9. miejsce ex aequo z reprezentacją Macedonii. W ramach promocji wydarzenia miasto wydało dwujęzyczny przewodnik kibica oraz mapę turystyczną, które udostępnione były na stronach Urzędu Miasta Łodzi lub m.in. w hotelach, na lotnisku, na dworcu Łódź Fabryczna. Ponadto w Manufakturze powstała strefa kibica, w której była możliwość pogrania w koszykówkę oraz obejrzenia meczów reprezentacji Polski. Na czas mistrzostw w Łodzi zostały również uruchomione dodatkowe linie tramwajowe i autobusowe (www.mm lodz.pl).

Mistrzostwa Europy Kobiet w Piłce Siatkowej (2009) również rozegrały się w Atlas Arenie, a mecze odbywały się w terminie od 25 września do 4 października. W Łodzi miały miejsce mecze pierwszej i drugiej fazy grupowej oraz fazy finałowej. W sumie w łódzkiej hali rozegrano 19 meczów. Reprezentacja Polski zajęła 3. miejsce. W ramach promocji imprezy zorganizowano na placu Dąbrowskiego Piknik Siatkarski, podczas którego można było wziąć udział w konkursach czy zagrać w siatkówkę.

Obydwa te wydarzenia zorganizowane w 2009 r. w łódzkiej Atlas Arenie przyczyniły się do wzrostu rozpoznawalności Łodzi oraz - jak podają władze samorządowe - miasto zyskało pozytywny wizerunek wśród turystów. Dzięki otwarciu Atlas Areny oraz rozegraniu $\mathrm{w}$ niej m.in. dwóch znaczących wydarzeń sportowych hala otrzymała status Sportowego Obiektu Roku 2009 (www.atlasarena.pl).

Rok 2011 to przede wszystkim zorganizowane m.in. w Łodzi Mistrzostwa Europy w Koszykówce Kobiet EurobasketWomen. Finałowa faza łódzka wydarzenia obejmowała pięć dni meczowych i rozgrywana była od 29 czerwca do 3 lipca. W mistrzostwach wzięło udział 16 reprezentacji narodowych, z których osiem awansowało do finału i rozgrywało mecze w Łodzi. Spotkania oglądało od 500 (ćwierćfinały) do 5000 kibiców (mecz finałowy Rosja-Turcja). Z wszystkich 12 meczów rozgrywanych w Łodzi 11 transmitowanych było „na żywo" przez różne telewizje europejskie oraz kanały internetowe. Wzorem największych imprez sportowych na świecie w pobliżu hali sportowej stworzono dobrze funkcjonującą strefę kibica (fan zone). 
Pomimo niewielkiej, jak na możliwości Atlas Areny, frekwencji na meczach, całe wydarzenie zostało pozytywnie ocenione zarówno przez instytucje międzynarodowe, jak i kibiców.

Poza mistrzostwami Europy w Łodzi odbyły się również inne imprezy o charakterze międzynarodowym. W hali łódzkiego MOSiR-u w listopadzie 2012 r. odbyła się Parada Jeździecka. Rok wcześniej impreza ta miała miejsce w Atlas Arenie, jednak nie przyciągnęła zbyt wielu widzów. Również w hali MOSiR-u w 2012 r. rozegrane zostały eliminacje do Pucharu Davisa. Poza większymi wydarzeniami sportowymi organizowane są w mieście przez cały czas imprezy sportowe o zasięgu lokalnym, regionalnym czy wojewódzkim (www.mosir.lodz.pl). Na łódzkim lodowisku „Bombonierka”, położonym przy ulicy Stefanowskiego 28, w 2014 r. odbył się Międzynarodowy Turniej w Hokeju na Lodzie POTZCUP.

Najważniejszymi wydarzeniami sportowymi dla miasta w 2014 r. były mecze fazy grupowej Mistrzostw Świata w Piłce Siatkowej Mężczyzn. W ramach zawodów rozegrano 12 meczów w tym sześć z udziałem reprezentacji Polski, która w całym turnieju zajęła 1. miejsce.

W lutym 2015 r. zorganizowano 11. edycję Halowego Mitingu Pedro's Cup. Zawody lekkoatletyczne zostały rozegrane w Atlas Arenie, a 26 września 2015 r. odbyła się w niej gala Polsat Boxing Night.

Tylko w ciągu ostatnich 10 lat w Łodzi odbyło się wiele imprez sportowych różnej rangi. Wydarzenia te powodują wzrost zainteresowania turystów miastem oraz przyczyniają się do zmiany wizerunku Łodzi, która staje się dzięki temu bardziej atrakcyjna nie tylko dla turystów sportowych.

Na fali sukcesu, jakim była organizacja Mistrzostw Świata w Piłce Siatkowej Mężczyzn, władze samorządowe powołały nową instytucję o nazwie Łódzkie Centrum Wydarzeń, które rozpoczęło swoją działalność w 2015 r. Głównym celem nowego organu jest promowanie wszelkich wydarzeń kulturalnych i sportowych organizowanych w mieście oraz pozyskanie i wsparcie organizacyjne kolejnych imprez o mniej lub bardziej masowym charakterze.

Największym niepowodzeniem w tym okresie, jeśli chodzi o organizację wielkich wydarzeń sportowych, była nieudana aplikacja związana $\mathrm{z}$ pomysłem organizacji w mieście Mistrzostw Europy UEFA Euro 2012. Ostatnie doniesienia medialne skłaniają do opinii, że prawdopodobnie niepomyślnie dla Łodzi zakończą się także starania związane $\mathrm{z}$ organizacją meczów Mistrzostw Europy w Piłce Siatkowej Mężczyzn, których gospodarzem będzie Polska w roku 2017.

\section{MISTRZOSTWA ŚWIATA W PIŁCE SIATKOWEJ MĘŻCZYZN 2014 - STUDIUM PRZYPADKU}

Mistrzostwa Świata w Piłce Siatkowej Mężczyzn odbywają się co cztery lata i mają charakter wielkiego międzynarodowego wydarzenia organizowanego przez Międzynarodową Federację Piłki Siatkowej FIVB (Federaction Internatinale de Volleyball). Do 2016 r. odbyło się 18 takich turniejów. Ceremonia otwarcia mistrzostw w 2014 r. odbyła się na Stadionie Narodowym w Warszawie i było to wydarzenie bez precedensu $\mathrm{w}$ dotychczasowej historii tej dyscypliny. W meczu otwarcia (Polska-Serbia) wzięło udział 61,5 tys. kibiców i zaproszonych gości. Polski Związek Piłki Siatkowej (PZPS) jako organizator krajowy wybrał siedem miast polskich, które spełniały wysokie wymagania co do posiadanego zaplecza sportowego, hotelowego, a także miały dobrą dostępność komunikacyjną. Oprócz Łodzi mecze rozgrywane były jeszcze w Bydgoszczy, Gdańsku, Katowicach, Krakowie, Wrocławiu oraz we wspomnianej już Warszawie. Ogółem od 30 sierpnia do 20 września odbyły się 103 mecze. Mecz finałowy Polska-Brazylia rozegrano w katowickim ,Spodku”.

Łódź jeszcze na długo przed rozpoczęciem mistrzostw rozpoczęła intensywną działalność promocyjną polegającą m.in. na kompleksowej informacji o wydarzeniu, działaniach reklamowych (takich jak wielkoformatowe banery, nowa szata środków komunikacji miejskiej i biletów MPK, imprezy poprzedzające zawody - Minimistrzostwa Świata w Siatkówce Polska 2014, udział w targach turystycznych w Londynie). Dodatkowo miasto przekazało PZPS prawie $7 \mathrm{mln}$ zł na działania promocyjne. Jednocześnie ekwiwalent promocyjny (reklamowy), czyli wartość publikacji w prasie, radiu i telewizji oraz Internecie (gdyby miasto musiało za nie zapłacić) oszacowany przez specjalistów wyniósł prawie 25,5 mln zł.

Dla osób, które z różnych powodów nie mogły oglądać meczów w Atlas Arenie zorganizowano na rynku Manufaktury „strefę kibica”, która cieszyła się bardzo dużym zainteresowaniem. Oprócz służb profesjonalnych (ochrona, ratownictwo medyczne itp.) w organizacji wydarzenia w Łodzi wzięło udział także 83 wolontariuszy pracujaccych w biurze prasowym, marketingu czy służbach informacyjnych i innych (SOBIERAJSKA 2015). W czasie trwania mistrzostw kibice za okazaniem biletu na mecz mogli bezpłatnie podróżować środkami komunikacji miejskiej, bezpłatnie korzystać ze wstępów do wybranych muzeów, pływalni, ogrodu zoologicznego i botanicznego oraz palmiarni.

W Atlas Arenie rozegrano mecze drugiej i trzeciej fazy grupowej oraz mecz o piąte miejsce. Na 13 meczów rozegranych przez reprezentację Polski w tych 
mistrzostwach w Łodzi rozegrano sześć. Pomimo dość wysokich cen biletów (od 80 do 290 zl) podczas ich trwania frekwencja wynosiła ponad 95\% (rys. 2).

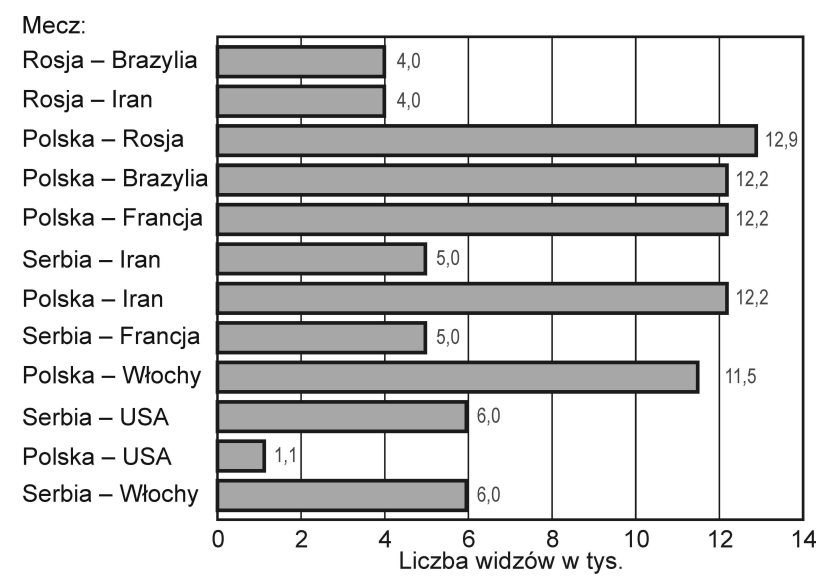

Rys. 2. Frekwencja podczas meczów rozgrywanych w Atlas Arenie

Źródło: www.lodz.gazeta.pl

Ogółem podczas wydarzenia Atlas Arenę odwiedziło 102,1 tys. kibiców. Na podstawie przeprowadzonych $\mathrm{w}$ trakcie imprezy badań można ocenić, że najczęściej byli to mieszkańcy Łodzi i województwa łódzkiego (35\%), mazowieckiego (25\%) i wielkopolskiego $(10 \%)$, a więc regionów położonych najbliżej miejsca organizacji wydarzenia. Liczba kibiców z pozostałych województw nie przekroczyła wartości 5\%. W każdym z meczów brały udział kilkudziesięcioosobowe grupy kibiców zagranicznych (w zależności od tego, kto rozgrywał mecz). Podczas organizacji mistrzostw najwyżej w pięciostopniowej skali oceniona została atmosfera wydarzenia $(4,83)$ i nagłośnienie obiektu $(4,64)$, najniżej - dostępność miejsc parkingowych $(3,68)$ (SOBIERAJSKA 2015).

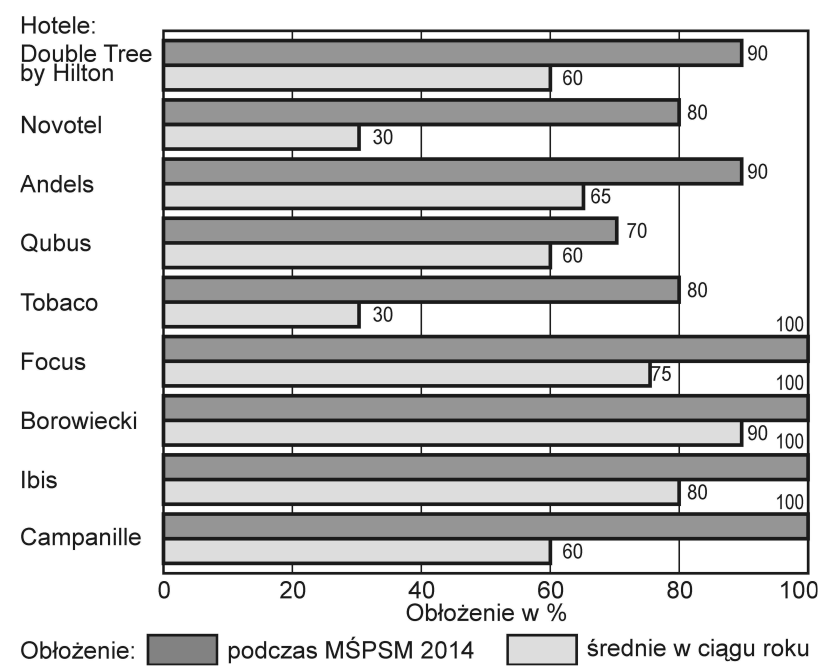

Rys. 3. Obłożenie wybranych łódzkich hoteli w ciągu roku oraz w trakcie MŚPSM 2014 Źródło: www.lodz.gazeta.pl
Aż 82\% wszystkich kibiców spoza Łodzi dotarło na mecze samochodem osobowym. Osobom poddanym badaniu podczas meczów najczęściej towarzyszyli znajomi $(44 \%)$ i rodzina $(43 \%)$. W $75 \%$ brały one udział tylko w jednym meczu. Można zatem zaklasyfikować je do tzw. odwiedzających jednodniowych (SOBIERAJSKA 2015). Nie przeszkodziło to uzyskać bardzo dobre wyniki sprzedaży łódzkim hotelom zlokalizowanym w niedalekiej odległości od Atlas Areny (rys. 3). Wartości obłożenia pokoi $\mathrm{w}$ czasie trwania mistrzostw były średnio od 10 do 50\% wyższe niż średnioroczne.

Wywiady przeprowadzone $\mathrm{z}$ gestorami łódzkiej bazy gastronomicznej, która również przygotowała się na mistrzostwa (m.in. poprzez wykupienie licencji do pokazywania meczów na telebimach i telewizorach, rabaty od 10 do $15 \%$ na posiłki i piwo dla posiadaczy biletów wstępu na mecze) sugerują, że zainteresowanie ofertą w czasie trwania mistrzostw dalekie było od oczekiwań.

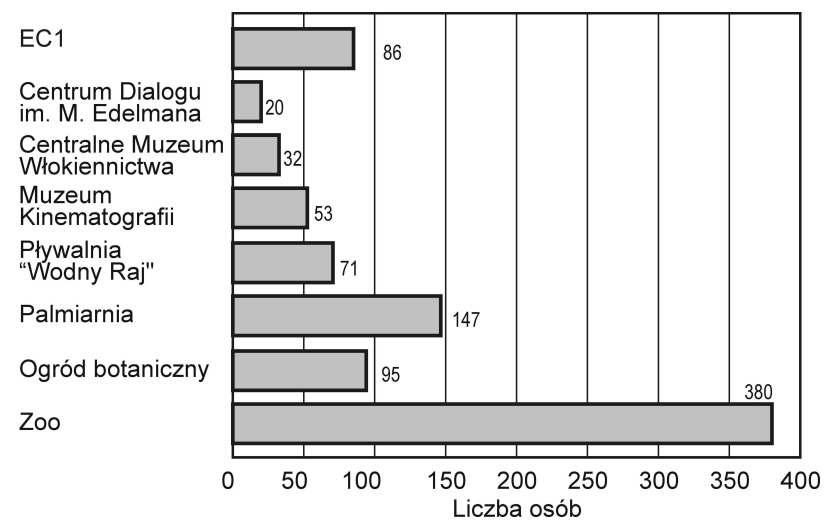

Rys. 4. Liczba odwiedzających Łódź w wybranych obiektach w trakcie MŚPSM 2014 za okazaniem biletu wstępu na mecz Źródło: www.lodz.gazeta.pl

Oferta uzupełniajacca przygotowana przez miasto w odniesieniu do liczby kibiców na meczach oraz w strefach kibica także nie cieszyła się specjalnym zainteresowaniem. W porównaniu z liczbą osób w Atlas Arenie ci, którzy odwiedzili muzea i pozostałe atrakcje stanowili niecały $1 \%$ fanoturystów (rys. 4). Niemniej jednak całe mistrzostwa okazały się dużym sukcesem jeśli chodzi o organizację i budowanie wizerunku Łodzi jako miasta przyjaznego wielkim imprezom sportowym i kibicom będaccym ich uczestnikami.

\section{PODSUMOWANIE}

Organizacja wielkich wydarzeń sportowych jest bardzo atrakcyjnym, ale także kosztownym, przedsięwzięciem dla większości dużych miast. Zazwyczaj osiągnięcie statusu miasta-gospodarza niesie ze sobą 
określone profity, które nie zawsze można, i należy, przeliczać wyłącznie na pieniądze. Czasami ważniejsze są aspekty wizerunkowe, a czasami wystarczy jedynie znaleźć się $\mathrm{w}$ doborowym towarzystwie. Łódź, która w ostatnich latach dokonała wyraźnego „skoku cywilizacyjnego" jeśli chodzi o dostępność komunikacyjną, wielkość oraz poziom bazy noclegowej i gastronomicznej, a także infrastrukturę sportową jest dobrym przykładem umiejętnego wykorzystania dużych wydarzeń sportowych do budowania pozytywnego wizerunku miasta przyjaznego zarówno organizowanym imprezom, jak i uczestniczącym w nich fanoturystom.

$\mathrm{Na}$ podstawie zaprezentowanych $\mathrm{w}$ artykule rozważań oraz przeprowadzonego studium przypadku nasuwają się następujące wnioski ogólne:

- organizowane $\mathrm{w}$ Łodzi wydarzenia sportowe przyczyniają się do wzrostu liczby turystów i w wyraźny sposób kształtują strukturę ruchu turystycznego;

- wydarzenia sportowe rangi krajowej i międzynarodowej skutkują pozytywnymi zmianami $\mathrm{w}$ postrzeganiu miasta przez osoby odwiedzające, które w większości dobrze lub bardzo dobrze oceniają ich organizację;

- kibice bioracy udział w wydarzeniach sportowych $\mathrm{w}$ mieście, poza udziałem $\mathrm{w}$ meczach, $\mathrm{W}$ niewielkim stopniu korzystają $\mathrm{z}$ innej niż sportowa dodatkowej oferty kulturalnej;

- pomimo niskiego poziomu uczestnictwa $\mathrm{w}$ imprezach towarzyszących kibice dobrze $\mathrm{i}$ bardzo dobrze oceniają atrakcyjność turystyczną Łodzi;

- największe korzyści z wydarzeń sportowych organizowanych $\mathrm{w}$ mieście odnosi branża hotelarska i gastronomiczna;

- sukcesy i profesjonalizm $\mathrm{w}$ organizacji dużych imprez sportowych, szczególnie siatkarskich (mecze ligowe, Liga Światowa, mistrzostwa Europy) spowodowały, że miasto $\mathrm{w}$ mediach nazywane jest stolicą polskiej siatkówki.

W przypadku opisywanego wydarzenia, jakim były Mistrzostwa Świata w Piłce Siatkowej Mężczyzn Łódź odniosła wyraźne korzyści wizerunkowe, o czym świadczy m.in. wartość wspomnianego ekwiwalentu reklamowego. Ale poza hotelami zlokalizowanymi w sąsiedztwie Atlas Areny i centrum miasta oraz wybranymi lokalami gastronomicznymi profity o charakterze ekonomicznym były dalekie od oczekiwań. Pozytywny jest natomiast fakt, że na fali sukcesu miasto w 2015 r. powołało Łódzkie Centrum Wydarzeń, którego celem jest promowanie cyklicznych wydarzeń kulturalnych i sportowych oraz wsparcie organizacyjne nowych imprez o charakterze masowym.

\section{BIBLIOGRAFIA}

ALEJZIAK W., 2008, Wielkie wydarzenia sportowe jako czynnik walki konkurencyjnej na globalnym rynku turystycznym, [w:] Turystyka jako czynnik wzrostu konkurencyjności regionów w dobie globalizacji, G. Gołembski (red.), Gremium Ekspertów Turystyki, Wyd. Akademii Ekonomicznej w Poznaniu, s. 52-66.

BOŃCZAK B., 2013a, Aktywne formy turystyki - problemy terminologiczne, [w:] Nowe-stare formy turystyki w przestrzeni, R. Wiluś, J. Wojciechowska (red.), ser. „Warsztaty z Geografii Turyzmu", 4, Wyd. Uniwersytetu Łódzkiego, Łódź, s. 49-62.

BOŃCZAK B., 2013b, Turystyka aktywna, kwalifikowana czy sportowa? Wzajemne relacje między zjawiskami w świetle literatury polskiej i zagranicznej, [w:] Wspótczesne uwarunkowania i problemy rozwoju turystyki, R. Pawlusiński (red.), Wyd. Uniwersytetu Jagiellońskiego, Kraków, s. 121-134.

BOSIACKI S., 2015, Wydarzenia sportowe jako atrakcja turystyczna na przyktadzie miasta Poznania, [w:] Turystyka sportowa - kulturowy potencjat i perspektywy rozwoju, M. Kazimierczak (red.) Akademia Wychowania Fizycznego im. Eugeniusza Piaseckiego w Poznaniu, Poznań, s. 119-128.

BORZYSZKOWSKI J., 2011, Wptyw eventu na rynek turystyczny - przykład ślubu księcia Williama i Kate Middleton, „Turystyka Kulturowa", 6, s. 4-16.

BRUMM K., 2012, Fanoturystyka - kibice sportowi w pozytywnym świetle, Wyd. K\&A K.M.A. Karasik, Poznań, ss. 84.

BUDNER W., 2014, Organizacja wielkich imprez sportowych jako wyraz wzrostu konkurencyjności miasta, Uniwersytet Ekonomiczny, Poznań, www.klub-biegacza.pl/artykuly/29/impre zy_sportowe_prof_budner.pdf.

FAULKNER B., 1993, Evaluating the Tourism Impact of Hallmark Events, Occasional Paper, 16, Bureau of Tourism Researche, Canberra, ss. 22.

GETZ D., 2008, Event Tourism: Definition, Evolution, Research, „Tourism Management”, 29, s. 403-428.

GIBSON H.J., 1998, Sport tourism: a critical analysis of research, „Sport Management Review”, 1, s. 45-76.

HADZIK A., 2014, Turystyka sportowa ze szczególnym uwzględnieniem międzynarodowych widowisk sportowych, AWF Katowice, ss. 131.

HADZIK A., TOMIK R., RYŚNIK J., 2015, Międzynarodowe widowisko sportowe jako przyktad produktu turystyki sportowej, [w:] Turystyka sportowa - kulturowy potencjat $i$ perspektywy rozwoju, M. Kazimierczak (red.), Akademia Wychowania Fizycznego im. Eugeniusza Piaseckiego w Poznaniu, Poznań, s. 129-137.

HiNCH T., HighAM J., 2011, Sport Tourism Development, Channel View Publ. - XVIII, Bristol, Buffalo, Toronto, ss. 258.

KACZMAREK J., STASIAK A., WŁODARCZYK B., 2010, Produkt turystyczny - pomyst, organizacja, zarządzanie, PWE, Warszawa, ss. 447.

KAZIMIERCZAK M., MALCHROWICZ-MOŚKO E., 2013, Turystyka sportowa - specyfika i trendy rozwojowe, „Folia Turistica”, 28 , s. 67-90.

KOZAK M., 2010, Wielkie imprezy sportowe - korzyść czy strata?, „Studia Regionalne i Lokalne”, 1(39), s. 48-69.

KOZAK M., 2015, Analiza mechanizmu wielkiej imprezy sportowej, [w:] Turystyka sportowa - kulturowy potencjat $i$ perspektywy rozwoju, M. Kazimierczak (red.), Akademia Wychowania Fizycznego im. Eugeniusza Piaseckiego w Poznaniu, Poznań, s. 18-27.

LISZEWSKI S. (red.), 2010, Ruch turystyczny w Łodzi i województwie tódzkim w 2009 roku, Regionalna Organizacja Turystyczna Województwa Łódzkiego, Łódź, ss. 176. 
MOKRAS-GRABOWSKA J., 2015, Turystyka aktywna - zagadnienia terminologiczne i klasyfikacje, [w:] Wczoraj, dziś i jutro turystyki aktywnej i specjalistycznej, A. Stasiak, J. Śledzińska, B. Włodarczyk (red.), Wyd. PTTK „Kraj”, Warszawa, s. 11-25.

OTTEVANGER H.J., 2007, Sport Tourism: Factor of influence on sport events visit motivation, Master of Arts in European Tourism Management, Bournemouth University (UK) s. 7-28.

PIECHOTA N., 2015, Zarys zatożeń metodologicznych badań nad wptywem wydarzeń sportowych $i$ turystyki biznesowej na konkurencyjność miast, [w:] Badania nad turystyką. Jeden cel, różne podejścia, M. Makowska-Iskierka (red.), ser. „Warsztaty z Geografii Turyzmu", 6, Wyd. Uniwersytetu Łódzkiego, Łódź, s. $149-158$

ROSE A. K., SPIEGEL M. M., 2011, Do mega sporting events promote international trade?, "SAIS Review of International Affairs", 31, 1, Winter-Spring, s. 77-85.

SOBIERAJSKA K., 2015, Wptyw wielkich wydarzeń sportowych na turystykę w Łodzi - przykład Mistrzostw Świata w Piłce Siatkowej Mężczyzn 2014 - praca magisterska napisana pod kier. prof. B. Włodarczyka w Instytucie Geografii Miast i Turyzmu UŁ.

STASIAK A., WŁODARCZYK B., 2015, Czy turystyka może nie być aktywna? O potrzebie podziałów i klasyfikacji turystyki, [w:] Wczoraj, dziś i jutro turystyki aktywnej i specjalistycznej, A. Stasiak, J. Śledzińska, B. Włodarczyk (red.), Wyd. PTTK „Kraj”, Warszawa, s. 39-51.

SZNAJDER A., 2015, Marketing sportu, PWE, Warszawa, ss. 310.

ŚNIADEK J., 2013, Wptyw megaeventów sportowych na społeczność i gospodarkę kraju goszczacego, ,Zeszyty Naukowe”, 26: Gospo- darka turystyczna w XXI wieku, Wyd. Wyższej Szkoły Handlu i Usług w Poznaniu, Poznań, ss. 124.

TUREK M., 2007, Wielkie imprezy sportowe $i$ ich dtugoterminowy wptyw na turystyke, [w:] Turystyka jako czynnik rozwoju społeczno-gospodarczego regionów europejskich, M. Turek (red.), Europejska Szkoła Hotelarstwa, Turystyki i Przedsiębiorczości Szkoła Wyższa w Sopocie, Sopot, ss. 42.

WEED M., BULL CH., 2005, Sport tourism: participations, policy and providers, Butterword-Heinemann, Oxford.

WŁODARCZYK B. (red.), 2011, Ruch turystyczny w Łodzi i województwie tódzkim w 2010 roku, ROTWŁ, Łódź, ss. 188.

WŁODARCZYK B. (red.), 2012, Ruch turystyczny w Łodzi $i$ województwie tódzkim w 2011 roku, ROTWŁ, Łódź, ss. 205.

http:/ / fotopolska.eu/stadiony; 10.06.2016.

http:/ / lodz.fotopolska.eu; 10.06.2016.

http:/ / myself.rogatek.pl; 10.06.2016.

http:/ / sportowefakty.wp.pl/zuzel/416277/ znamy-wizualiza cje-stadionu-orla-lodz; 10.06.2016.

http://stadiony.net/stadiony/pol/stadion_lks_lodz; 10.06.2016. http://www.eventim.pl; 10.06.2016.

http:/ / www.fakt.pl/sport/ pilka-nozna; 10.06.2016.

https://www.youtube.com; 10.06.2016.

www.atlasarena.pl; 10.06.2016.

www.lodz.gazeta.pl; 10.06.2016.

www.lodz.sport.pl; 10.06.2016.

www.mmlodz.pl; 10.06.2016.

www.mosir.lodz.pl; 10.06.2016. 